\title{
Corrosion Behavior of the Stressed Sensitized Austenitic Stainless Steels of High Nitrogen Content in Seawater
}

\author{
A. Almubarak, ${ }^{1}$ W. Abuhaimed, ${ }^{1}$ and A. Almazrouee ${ }^{2}$ \\ ${ }^{1}$ Deptartment of Chemical Engineering, College of Technological Studies, P.O. Box 42325, 70654 Shuwaikh, Kuwait \\ ${ }^{2}$ Deptartment of Mechanical Production Technology, College of Technological Studies, P.O. Box 42325, 70654 Shuwaikh, Kuwait
}

Correspondence should be addressed to A. Almubarak; fort_collins9@yahoo.com

Received 28 March 2013; Accepted 22 April 2013

Academic Editor: Sheng S. Zhang

Copyright (C) 2013 A. Almubarak et al. This is an open access article distributed under the Creative Commons Attribution License, which permits unrestricted use, distribution, and reproduction in any medium, provided the original work is properly cited.

\begin{abstract}
The purpose of this paper is to study the effect of high nitrogen content on corrosion behavior of austenitic stainless steels in seawater under severe conditions such as tensile stresses and existence of sensitization in the structure. A constant tensile stress has been applied to sensitized specimens types 304, 316L, 304LN, 304NH, and 316NH stainless steels. Microstructure investigation revealed various degrees of stress corrosion cracking. SCC was severe in type 304, moderate in types 316L and 304LN, and very slight in types $304 \mathrm{NH}$ and $316 \mathrm{NH}$. The electrochemical polarization curves showed an obvious second current peak for the sensitized alloys which indicated the existence of second phase in the structure and the presence of intergranular stress corrosion cracking. EPR test provided a rapid and efficient nondestructive testing method for showing passivity, degree of sensitization and determining IGSCC for stainless steels in seawater. A significant conclusion was obtained that austenitic stainless steels of high nitrogen content corrode at a much slower rate increase pitting resistance and offer an excellent resistance to stress corrosion cracking in seawater.
\end{abstract}

\section{Introduction}

Austenitic stainless steels have been used successfully in many applications in marine environment. Types 304 and 316L are the most likely candidates for marine applications due to their excellent corrosion resistance especially for pitting and crevice. Therefore, they are found in excess in workboat propellers, pump components, valves, shaft components, hull fittings, fasteners, and oceanographic instruments [1]. Type 316L stainless steels are considered to be the main components in hydraulic control systems for the operation of subsea oil recovery system. These alloys also are used in instrument and chemical injection tubing in offshore oil platform [2-4].

In many marine applications, the corrosion resistance of the traditional types 304/316L stainless steels may not be sufficient, particularly for more demanding applications such as continuous immersion or exposure at elevated temperatures. It has been shown by the Welding Research Council [5] that 300 series stainless steels, heavily sensitized by furnace heat treatment, displayed intergranular corrosion in ambient seawater exposures. Austenitic stainless steels are generally susceptible to stress corrosion cracking (SCC) in chloride containing environments at high temperature. This type of cracking, defined as chloride stress corrosion cracking (CSCC), is mostly transgranular in nature and is not affected by the change in metallurgical structure of alloys [6].

High nitrogen stainless steels (HNSS) are becoming an important class of engineering materials and have received much attention in recent years. The effects of nitrogen on the properties of steels have long been a subject of study. Nitrogen-alloyed steels are considered HNSS, when the nitrogen content exceeds $0.4 \mathrm{wt} \%$ in austenite matrix and $0.08 \mathrm{wt} \%$ in the case of ferritic structure [7]. Nitrogen alloying in stainless steels is known to have many beneficial effects, including improvements in phase stability, strengthening, and corrosion resistance. Austenitic HNSS find wide applications today in chemical equipment, power generation industry, petroleum and nuclear industries, marine sectors, and ship building [8-10].

The role of nitrogen in the passivity of stainless steels has been explained through several mechanisms. Baykal et al. [11] 
TABLE 1: Major ion composition of Arabian Gulf Seawater (Kuwait).

\begin{tabular}{lc}
\hline Ion & Concentration $(\mathrm{mg} / \mathrm{L})$ \\
\hline Chloride $\left(\mathrm{Cl}^{-}\right)$ & 23,650 \\
Sodium $\left(\mathrm{Na}^{+}\right)$ & 15,560 \\
Sulfate $\left(\mathrm{SO}_{4}{ }^{2-}\right)$ & 3,220 \\
Magnesium $\left(\mathrm{Mg}^{2+}\right)$ & 1,665 \\
Calcium $\left(\mathrm{Ca}^{2+}\right)$ & 510 \\
Potassium $\left(\mathrm{K}^{+}\right)$ & 465 \\
Bicarbonate $\left(\mathrm{HCO}_{3}{ }^{-}\right)$ & 140 \\
Others & 190 \\
\hline Total dissolved solids & 45,400 \\
\hline
\end{tabular}

stated that nitrogen addition in stainless steels improves their pitting and crevice corrosion resistance, and this improvement is directly correlated to the nature of the passive film formed on the steels. It has been attributed that the beneficial effect of nitrogen on localized corrosion is due to the enrichment of nitrogen in the oxide/metal interface during passivation.

Hänninen et al. [12] concluded that nitrogen-alloyed austenitic stainless steels improve the resistance to localized corrosion, in general, and in some environments resistance to general corrosion. Nitrogen alloying has been observed to retard localized corrosion initiation and to suppress the growth of the localized corrosion attack effectively by an immediate repassivation. This was suggested to be due to formation of $\mathrm{NH}_{4}{ }^{+}$in initiated pits/crevices increasing locally the $\mathrm{pH}$ value and enhancing repassivation.

It is well known that alloying of nitrogen in stainless steels improves a number of corrosion properties. However, the mechanistic role of nitrogen in improving the corrosion resistance is still under intensive investigation and needs more study. Nitrogen alloying improves the cavitation erosion resistance of austenitic stainless steels in ocean. The main reason for the increase in cavitation erosion resistance of austenitic stainless steels is the effect of nitrogen on their hardness [13].

In this research an attempt was made to investigate corrosion behavior for different grades of stressed sensitized austenitic stainless steel in seawater. Types 304 and 316L stainless steels are traditional types and commonly used in marine environment applications. Type 304LN represents austenitic stainless steel with low nitrogen content. These types have been compared with types $304 \mathrm{NH}$ and $316 \mathrm{NH}$ austenitic stainless steels to study the effect of high nitrogen content on the corrosion resistance.

Immersed specimens in seawater were subjected to a constant tensile stress. Experimental work that included corrosion rate, microstructure investigation, and electrochemical test has been carried out for the stressed sensitized austenitic stainless steel specimens. Seawater was taken from the deep sea of Arabian Gulf (Kuwait: N $28^{\circ} 54$ 00; E $48^{\circ} 4400$ ) to be used for this research. Table 1 shows ion composition of the used seawater sample.

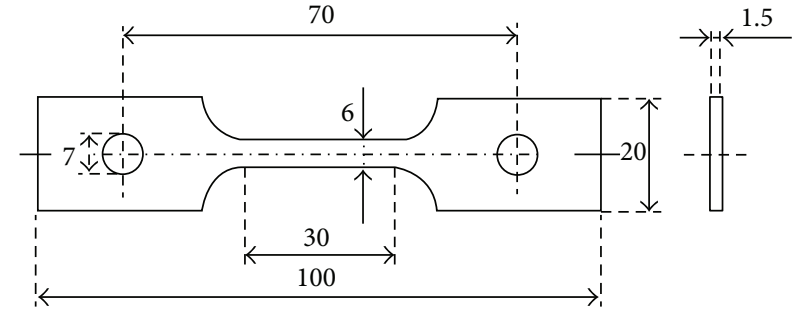

FIGURE 1: Geometry of the stainless steel specimen in $\mathrm{mm}$.

\section{Experimental Program}

2.1. Materials. A series of tests was carried out to evaluate five types of austenitic stainless steels in seawater. The materials studied were commercial austenitic stainless steels types 304 , $316 \mathrm{~L}, 304 \mathrm{LN}, 304 \mathrm{NH}$, and $316 \mathrm{NH}$. Types $304 \mathrm{NH}$ and $316 \mathrm{NH}$ alloys, which have high nitrogen content, have been selected to study the effect of nitrogen on the corrosion behavior. Chemical compositions (wt\%) for the steels are shown in Table 2. Yield strength and ultimate tensile strength for the stainless steel specimens at room temperature are shown in Table 3. The specimens have been prepared with geometry and dimensions shown in Figure 1.

2.2. Heat Treatment. Most stainless steel alloys used in marine application equipment are solution annealed in the as-received condition. In certain cases, the austenitic stainless steels are subjected to welding or high temperature exposure where temperature reaches up to $550^{\circ} \mathrm{C}$ such as that in heater tubes. This temperature, with long time exposure, is enough to create sensitization inside the grain boundaries. Therefore, the specimens had been heat treated to simulate the effect of welding and high temperature exposure. The sensitization range is $450^{\circ} \mathrm{C}-850^{\circ} \mathrm{C}$ and the most critical temperature is $650^{\circ} \mathrm{C}[14]$.

The austenitic stainless steel specimens were prepared by different heat treatment conditions. First, all the specimens were solution annealed at $1080^{\circ} \mathrm{C}$ for $1 / 2$ hour and then water was quenched before testing, since this is the normal asreceived condition. Second, the specimens were sensitized at $650^{\circ} \mathrm{C}$ for 2 hours and then allowing air cooled.

2.3. Apparatus Structure. An Apparatus has been designed and installed especially for this research. The apparatus has a beam of rectangular shape supported by two horizontal beams as shown in Figure 2. A pull cylinder (Enerpac BRP106C) has been hung from the upper horizontal beam by a hook. A tube was connected between the pull cylinder and a hydraulic hand pump (Enerpac P-392) to exert a pressure inside the cylinder. The immersed specimen in seawater was subjected to a constant tensile stress of $240 \mathrm{MPa}$.

A stainless steels bucket was fixed and held by two bending steel bars from both sides. This situation allowed the bucket to bear the high tensile stress by the pull cylinder. The stainless steel specimen was tightened from one end, by a strong stainless steel chain, to the bottom of the bucket. The top-side end of specimen was connected, by a longer chain, to 
TABLE 2: Chemical composition of stainless steel specimens.

\begin{tabular}{lccccccccc}
\hline & $\mathrm{C}$ & $\mathrm{Mn}$ & $\mathrm{Si}$ & $\mathrm{Cr}$ & $\mathrm{Ni}$ & $\mathrm{Mo}$ & $\mathrm{S}$ & $\mathrm{P}$ & $\mathrm{N}$ \\
\hline 304 & 0.06 & 1.61 & 0.30 & 18.22 & 8.40 & 0.20 & 0.01 & 0.03 & 0.01 \\
$316 \mathrm{~L}$ & 0.03 & 1.50 & 0.47 & 16.90 & 11.00 & 2.35 & 0.01 & 0.03 & 0.01 \\
$304 \mathrm{LN}$ & 0.03 & 1.62 & 0.40 & 18.40 & 8.45 & 0.00 & 0.02 & 0.03 & 0.16 \\
$304 \mathrm{NH}$ & 0.04 & 1.62 & 0.40 & 18.41 & 8.44 & 0.24 & 0.02 & 0.03 & 0.52 \\
$316 \mathrm{NH}$ & 0.04 & 1.50 & 0.48 & 16.94 & 12.01 & 1.40 & 0.02 & 0.04 & 0.64 \\
\hline
\end{tabular}

TABLE 3: Yield strength and ultimate tensile strength in MPa of the stainless steel specimens at room temperature.

\begin{tabular}{lccccc}
\hline & 304 & $316 \mathrm{~L}$ & $304 \mathrm{LN}$ & $304 \mathrm{NH}$ & $316 \mathrm{NH}$ \\
\hline YS & 314 & 248 & 368 & 424 & 482 \\
UTS & 612 & 524 & 690 & 746 & 840 \\
\hline
\end{tabular}

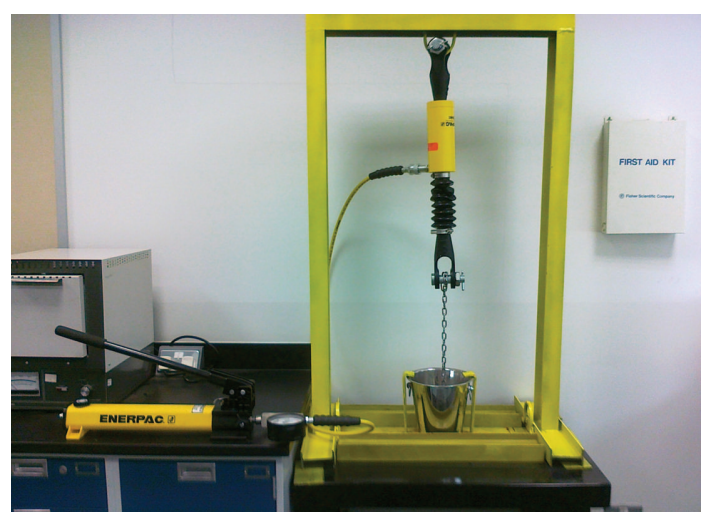

Figure 2: Apparatus structure composed of rectangular beam, hydraulic hand pump, pull cylinder, and stainless steel bucket.

the pull cylinder as shown in Figure 3. A rubber tube, which was extended from a small air pump, was fixed at the bottom of the bucket to bubble oxygen inside the seawater sample. Air bubbling, though, makes the seawater sample in a continuous motion (almost turbulent flow).

2.4. Experimental Procedure. The sensitized specimen was fixed inside the bucket in a manner as described before. The bucket was filled with seawater at ambient temperature $\left(24^{\circ} \mathrm{C}-27^{\circ} \mathrm{C}\right)$. Seawater has been changed every 10 days to assure clean seawater present all time. After 120 days the experiment has been stopped and the specimen was cleaned by distilled water carefully to remove any adhesive salts. The specimen was weighted by a digital balance to calculate corrosion rate. The specimen was subjected to electrochemical potentiokinetic reactivation (EPR) test and an anodic polarization curve was recorded.

The specimen was then subjected to microstructure investigation to determine the type of corrosion. An electrolytic etching in oxalic acid $\left(\mathrm{C}_{2} \mathrm{H}_{2} \mathrm{O}_{4}\right)$ has been used for grain structure examination. The etched surface was rinsed with deionized water and alcohol and then dried. The cross section of the tested specimen was examined using an optical

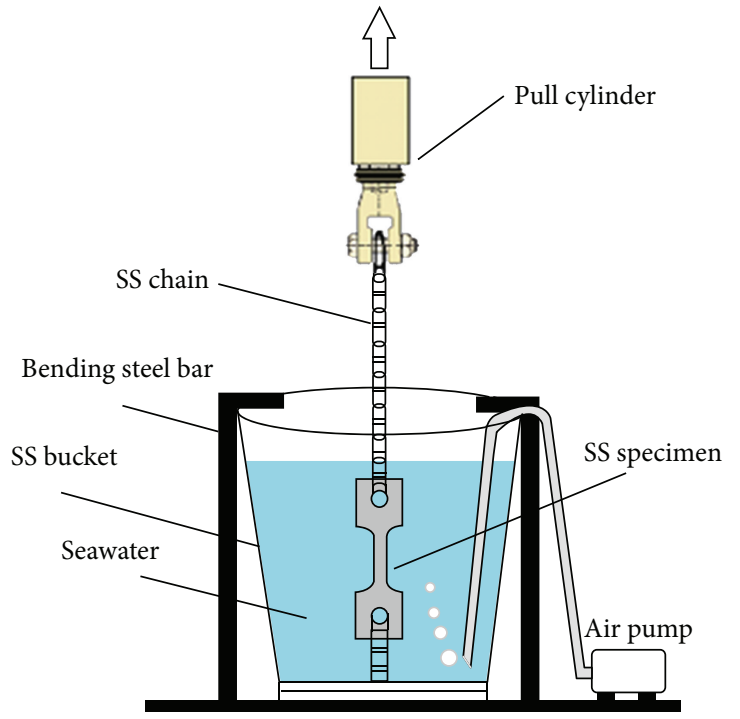

FIgURE 3: The figure Drawing shows the position of the specimen in the steel bucket.

microscopy to investigate the corrosion condition of grain boundaries.

Every specimen was subjected, individually, to a constant tensile stress $(240 \mathrm{MPa})$ and immersed in seawater for 120 days. Therefore, more than 20 months were spent to complete the five different grades of stainless steels. The same procedures of electrochemical and metallographic tests have been repeated for all the test specimens.

2.5. Electrochemical Test. Sensitization creates potential differences between grain boundaries and the matrix, which means that an attack can be determined by availability of anodic sites at grain boundaries. Some researchers developed electrochemical potentiokinetic techniques as a rapid, quantitative, and nondestructive test method to evaluate the degree of sensitization [15-18].

In the current investigation, EPR tests have been applied to establish anodic polarization curves for stainless steel specimens. The electrochemical test equipment consisted of a potentiostat (GAMRY 300), a stainless steel specimen as a working electrode, a platinum counter electrode $1.50 \mathrm{in}^{2}$ area, and a reference electrode (saturated calomel electrode, SCE). Each specimen was polished on successive finer grades of emery papers from 120 grit to 600 grit. The polarization test was carried out in a solution of $0.5 \mathrm{M}$ sulfuric acid 
TABLE 4: Corrosion rate for specimens in seawater in (mpy) and pitting resistance equivalent (PRE).

\begin{tabular}{lccccc}
\hline Type of SS & 304 & $316 \mathrm{~L}$ & $304 \mathrm{LN}$ & $304 \mathrm{NH}$ & $316 \mathrm{NH}$ \\
\hline Corrosion rate & 2.460 & 1.601 & 1.422 & 0.661 & 0.428 \\
PRE & 19.18 & 24.96 & 23.20 & 34.80 & 40.76 \\
\hline
\end{tabular}

$\left(\mathrm{H}_{2} \mathrm{SO}_{4}\right)+0.01 \mathrm{M}$ potassium thiocyanate $(\mathrm{KSCN})$, deaerated by passing argon for one hour before and during the experiment, at ambient temperature $\left(26^{\circ} \mathrm{C}\right)$. After immersion in the solution for approximately one hour, the specimen was polarized at ambient temperature using a scan rate of $0.6 \mathrm{~V} / \mathrm{hr}$ and a scan range from $-0.8 \mathrm{~V}$ to $+1.2 \mathrm{~V}$. Data were recorded using a personal computer-based data logging system with a carrier frequency amplifier measuring unit.

\section{Discussion and Results}

3.1. Microstructure Investigations. Microstructure investigations for the stressed sensitized type 304 in seawater are shown in Figure 4(a). A severe chloride stress corrosion cracking (CSCC) has been noticed in the specimen. The microstructure investigation showed the presence of branching intergranular and transgranular cracks. The microstructure of the specimen type 316L showed a classical branching CSCC, where the transgranular nature was obvious (Figure 4(b)). However, intergranular stress corrosion cracking was also noticed in the specimen structure. Microstructure results for type 304LN in the seawater (Figure 5) showed amount of cracks almost similar to that obtained for type 316L. Multiple intergranular and transgranular cracks can be observed clearly in this structure.

The beneficial effect of alloying nitrogen in austenitic stainless steels appeared clearly in the two types $304 \mathrm{NH}$ and $316 \mathrm{NH}$. Only very slight SCC has been observed in the microstructure examination (Figure 6) for the austenitic type $304 \mathrm{NH}$, whereas hair line cracks appeared in Figure 7 for type $316 \mathrm{NH}$. Microstructure investigation for the sensitized specimens led to a result that austenitic stainless steels of high nitrogen content are excellent resisting stress corrosion cracking in seawater.

Pitting has been noticed also through microstructure investigations for the stressed sensitized specimens in seawater. Figure 4(a) showed several significant pits in type 304. Figure 4(b) showed some small size pits in type 316L. Also, some pits in type 304LN, which have small sizes, have been noticed in Figure 5. Again, the effect of high nitrogen content on stainless steels can be noticed clearly in types $304 \mathrm{NH}$ and 316 NH. Figure 6 showed few small pits, whereas Figure 7 showed almost no pits for the microstructures $304 \mathrm{NH}$ and $316 \mathrm{NH}$, respectively.

The pitting resistance equivalent (PRE) of stainless steels containing nitrogen is defined as $\mathrm{PRE}=1[\mathrm{Cr}]+3.3[\mathrm{Mo}]+$ $x[\mathrm{~N}]$, with $x$ being between about 13 and 30 [19]. It has been reported that using a coefficient of 30 for nitrogen allowed the best fit to experimental data for a wide range of nitrogenalloyed austenitic steels [20]. Table 4 showed high PRE values for types $304 \mathrm{NH}$ and $316 \mathrm{NH}$ due to their higher nitrogen content. Microstructure investigation results agreed well with the correlation of PRE, which attributes that stainless steels of high nitrogen content increase the resistance to pitting.

The current work has been done in a short period (120 days) for different grades of stainless steels where a severe SCC had occurred in certain sensitized specimens. In real marine applications, however, it would be better to assume that some sensitization will occur in the unsensitized stainless steels over extended periods of time, that is, 1-2 years or more. This is particularly true for severe high temperature service such as in welding process, electric power plant condensers and offshore oil production equipment.

3.2. Polarization Curves. Anodic polarization curves have been established by the application of EPR test to the stressed sensitized specimens. The polarization test was carried out in a solution of $0.5 \mathrm{M}$ sulfuric acid $\left(\mathrm{H}_{2} \mathrm{SO}_{4}\right)+0.01 \mathrm{M}$ potassium thiocyanate $(\mathrm{KSCN})$ at $26^{\circ} \mathrm{C}$. Figure 8 showed the anodic polarization curves for the austenitic stainless steels types 304, 316L, and 304LN. The anodic curves demonstrated clear active-passive transitions. Passive regions were with a range of $-10 \mathrm{mV}$ to $+950 \mathrm{mV}$ in these curves. The sensitized types $304 \mathrm{NH}$ and $316 \mathrm{NH}$ (Figure 9) gave a wider passivity region than those of types $304,316 \mathrm{~L}$ and $304 \mathrm{LN}$, which suggests that the passivation of steels of high nitrogen content is better than the other alloys.

The anodic polarization curves in Figure 8 showed also an obvious second current peak, which indicates the existence of a second phase in the alloy structure. The second phase usually forms during sensitization process of stainless steels where chromium carbides $(\mathrm{Fe}, \mathrm{Cr})_{23} \mathrm{C}_{6}$ precipitate in the regions adjacent to the grain boundaries, resulting in depletion of chromium as shown in Figure 10. In a previous paper [21], a second current peak in the electrochemical testing of stressed sensitized types 304 and 316 stainless steels in polythionic acid and chloride solution was also noticed. It was concluded that the second current peak was due to the difference in concentration of chromium content between the grain boundaries and the matrix. Sensitization, in general, makes a depletion of chromium in the adjacent area to grain boundaries. Applying tensile stresses on the sensitized material usually leads to an intergranular stress corrosion cracking (IGSCC). Therefore, the second anodic current peak in the anodic curves may also indicate the presence of IGSCC.

Almost, similar polarization curves have been obtained for the types $304 \mathrm{NH}$ and $316 \mathrm{NH}$ specimens (Figure 9). However, smaller second anodic current peaks were observed with these two types of steels, which means these alloys have less degree of sensitization and may have slight IGSCC.

The plots shown in Figures 8 and 9 indicated that the second anodic current peaks were at $884 \mu \mathrm{A} / \mathrm{cm}^{2}, 583 \mu \mathrm{A} / \mathrm{cm}^{2}$, $402 \mu \mathrm{A} / \mathrm{cm}^{2}, 101 \mu \mathrm{A} / \mathrm{cm}^{2}$, and $92 \mu \mathrm{A} / \mathrm{cm}^{2}$ for the types 304 , $316 \mathrm{~L}, 304 \mathrm{LN}, 304 \mathrm{NH}$, and $316 \mathrm{NH}$, respectively. Obviously, the second current peaks values for types $304 \mathrm{NH}$ and $316 \mathrm{NH}$ were smaller than the other austenitic types. 


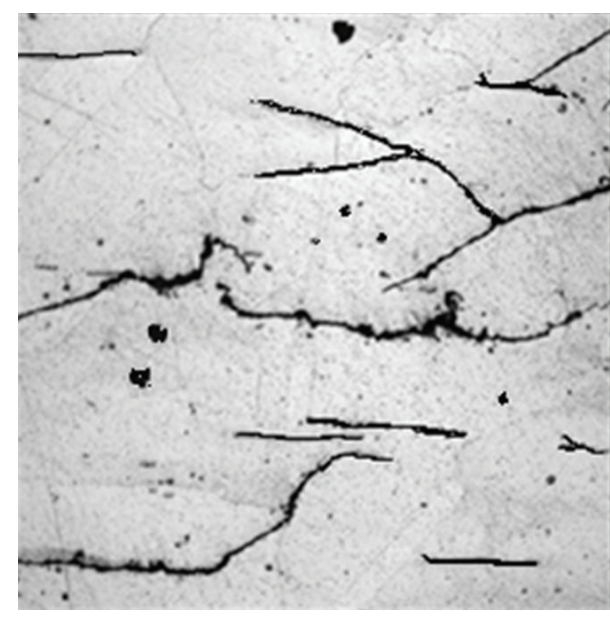

(a)

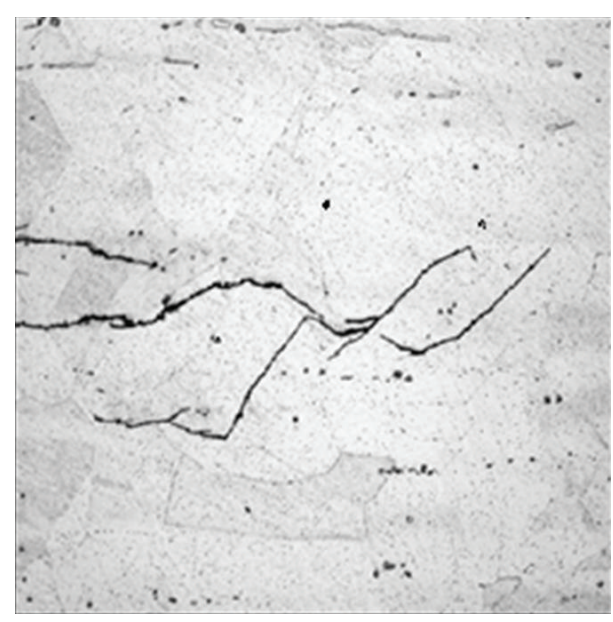

(b)

FIgURE 4: (a) Austenitic stainless steel type $304(80 \mu \mathrm{m})$ showing a severe chloride stress corrosion cracking and several large pits. (b) Austenitic stainless steel type $316 \mathrm{~L}(80 \mu \mathrm{m})$ showing a classical chloride stress corrosion cracking and small size pits.

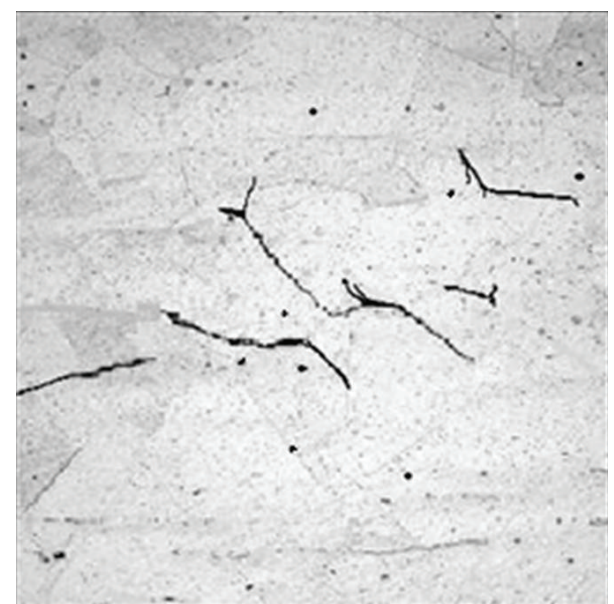

FIGURE 5: Austenitic stainless steel type 304LN ( $80 \mu \mathrm{m})$ showing a classical chloride stress corrosion cracking and small size pits.

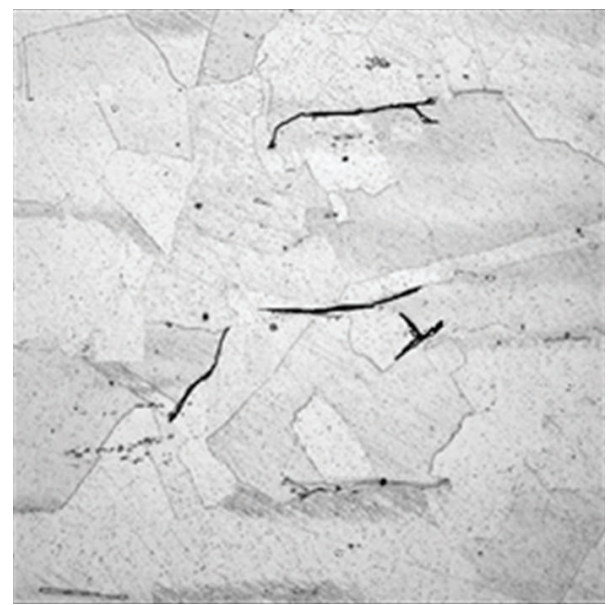

FIGURE 6: Austenitic stainless steel type 304NH ( $80 \mu \mathrm{m})$ showing a very slight stress corrosion cracking and few small pits.

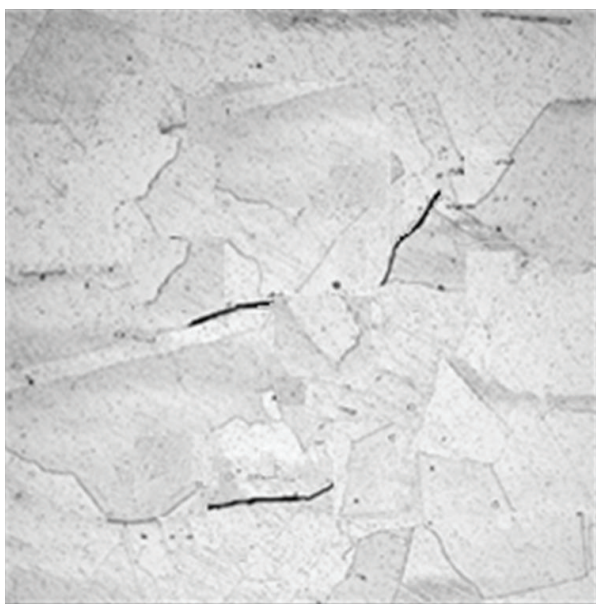

FIGURE 7: Austenitic stainless steel type $316 \mathrm{NH}(80 \mu \mathrm{m})$ showing hair line cracks and no pits.

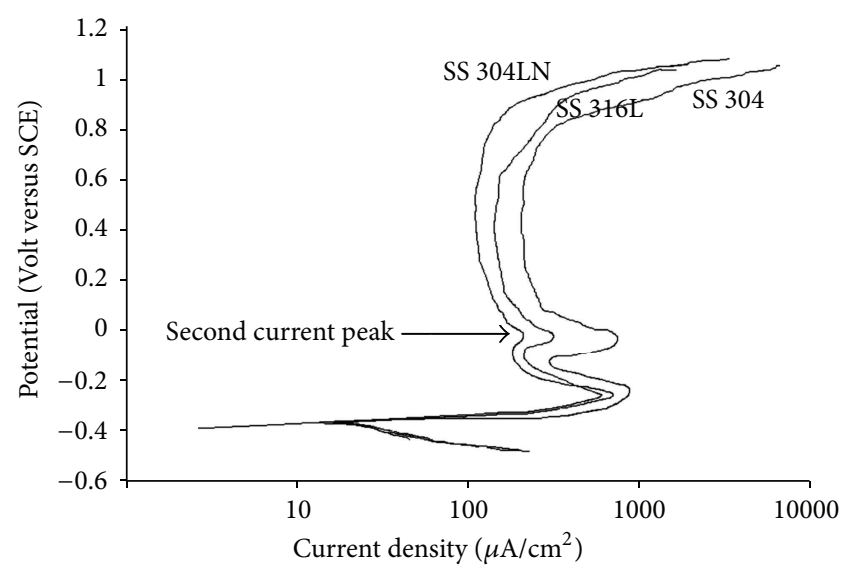

Figure 8: Anodic polarization curve for types 304, 316L, and 304LN austenitic stainless steels in a solution of $0.5 \mathrm{M}$ sulfuric acid $\left(\mathrm{H}_{2} \mathrm{SO}_{4}\right)+0.01 \mathrm{M}$ potassium thiocyanate $(\mathrm{KSCN})$ at $26^{\circ} \mathrm{C}$. 


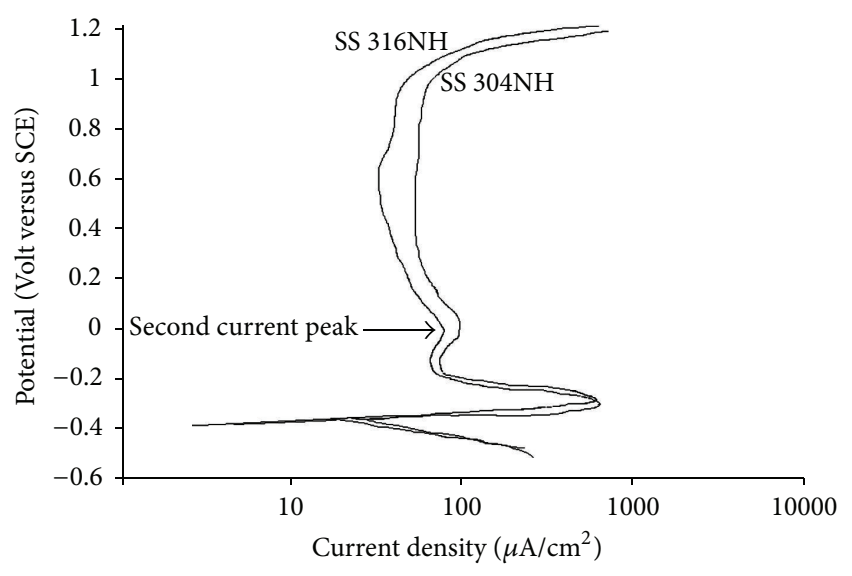

FIGURE 9: Anodic polarization curve for types $304 \mathrm{NH}$ and $316 \mathrm{NH}$ austenitic stainless steels, in a solution of $0.5 \mathrm{M}$ sulfuric acid $\left(\mathrm{H}_{2} \mathrm{SO}_{4}\right)+0.01 \mathrm{M}$ potassium thiocyanate $(\mathrm{KSCN})$ at $26^{\circ} \mathrm{C}$.

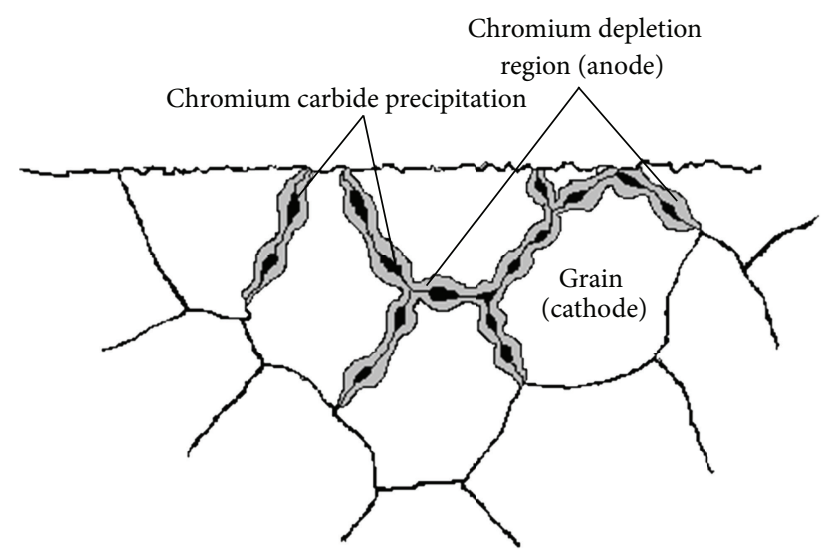

FIGURE 10: Schematic representation of precipitation of chromium carbide $(\mathrm{Fe}, \mathrm{Cr})_{23} \mathrm{C}_{6}$ at the grain boundaries during sensitization in stainless steel.

This result with the result of microstructure investigations leads to a conclusion that austenitic stainless steels of high nitrogen content, in general, offer a significant resistance to intergranular stress corrosion cracking when exposed to seawater. This conclusion agreed well with the result obtained by Pozuelo et al. [22] on a clear beneficial effect of nitrogen alloying on intergranular stress corrosion cracking behavior in chloride solutions.

3.3. Corrosion Rate. The corrosion rate was calculated for each specimen according to the following formula:

$$
\text { Corrosion Rate }(\mathrm{mpy})=\frac{534 \times W}{D A T},
$$

where $W$ is weight loss in $\mathrm{mg}, D$ is density of specimen in $\mathrm{g} / \mathrm{cm}^{3}, A$ is total area of specimen for both sides in in $^{2}$ and $T$ is time exposed in hr. Table 4 shows corrosion rate for the specimens after 120 days in seawater.

As it was expected, corrosion rate values were almost negligible and limited between the different grades of austenitic stainless steels. However, the estimated values indicated to reasonable remarks. Corrosion rate was less in type $316 \mathrm{~L}$ than that in type 304 due to its higher molybdenum content. However, the corrosion rate in type $304 \mathrm{LN}$, which is free of molybdenum, is almost equal to the corrosion rate value of type 316L. This value meant that nitrogen content in type $304 \mathrm{LN}$ may provide a reasonable corrosion resistance to the alloy. Obviously, the specimens $304 \mathrm{NH}$ and $316 \mathrm{NH}$ reported less corrosion rate values than the other grades. This behavior assures that high nitrogen content assists in creating resistance to the corrosion process in the alloy steel.

Austenitic stainless steels of high nitrogen content offered less corrosion rates and exhibited an excellent resistance to stress corrosion cracking and to pitting when exposed to seawater. The traditional types 304/316L stainless steels have adequate corrosion resistance for many mildly corrosive marine applications. In general, type 316 L stainless steel is more corrosion resistant in marine applications than type 304 stainless steel due to its higher molybdenum content. The new austenitic stainless steels, called the super austenitic grades, contain high levels of molybdenum $(5 \%-7 \%)$ and are sometimes referred to as $6 \%$ molybdenum or 6 moly stainless steels. These alloys are resistant to corrosion under highly corrosive conditions, including seawater immersion at ambient and elevated temperature [23]. However from an economic standpoint molybdenum is very expensive and the market for stainless steels is very competitive. Therefore, selection of stainless steels with higher content of nitrogen for severe marine applications, such as power generation plants, heater tubes, and offshore oil production facilities, seems wiser.

\section{Conclusion}

It has been concluded that stressed sensitized austenitic stainless steels of high nitrogen content, corroded at a much slower rate, increased the pitting resistance and exhibited an excellent resistance to stress corrosion cracking in seawater. The electrochemical polarization curves showed an obvious second current peak for the sensitized alloys which indicates the existence of a second phase in the alloy structure and the presence of an intergranular stress corrosion cracking. EPR test provided a rapid and efficient non-destructive testing method for showing passivity, degree of sensitization and determining IGSCC for stainless steels in seawater.

The general experience in marine environment with austenitic stainless steel equipment has showed a successful operation in seawater at moderate's temperatures (i.e., $<100^{\circ} \mathrm{C}$ ). Austenitic stainless steel of high nitrogen content can be more satisfactory for marine sectors and offshore service such as heater tubes, ship building, and power generation in marine tankers where equipment is exposed to tensile stresses and elevated temperatures.

\section{References}

[1] K. A. Chandler, Marine and Offshore Corrosion, Butterworth, London, UK, 1985. 
[2] G. E. Moller, "The successful use of austenitic stainless steel in sea water," Society of Petroleum Engineers Journal, vol. 4, pp. 3545, 1977.

[3] L. Zheng, A. Neville, A. Gledhill, and D. Johnston, "Investigation into the corrosion behavior of stainless steel $316 \mathrm{~L}$ in hydraulic fluids for subsea applications," in Proceedings of the NACE Corrosion Conference (Corrosion '08), no. 08236, Houston, Tex, USA, 2008.

[4] A. Kopliku and C. Mendez, "316 Stainless steel instrument tubing in marine applications-localized corrosion problems and solutions," in Proceedings of the NACE Corrosion Conference (Corrosion '10), no. 10305, Houston, Tex, USA, 2010.

[5] Welding Research Council and WRC Bulletin, "Intergranular corrosion of chromium-nickel stainless steels," Tech. Rep. 138, New York, NY, USA, 1969.

[6] P. R. Rhodes, "Environment-assisted cracking of corrosionresistant alloys in oil and gas production environments: a review," Corrosion, vol. 57, no. 11, pp. 923-966, 2001.

[7] M. Kikuchi and Y. Mishima, "High nitrogen steels," in Proceedings of the Conference on High Nitrogen Steels (HNS '95), Kioto, Japan, 1996.

[8] M. O. Speidel, "Properties and applications of high nitrogen steels," in Proceedings of the Conference on High Nitrogen Steels (HNS '88), Lille, France, 1989.

[9] V. Gavriljuk and V. Nadutov, "High nitrogen steels," in Proceedings of the Conference on High Nitrogen Steels (HNS '93), Kiev, Ukraine, 1993.

[10] R. Ritzenhoff and A. Hahn, "Corrosion resistance of high nitrogen steels," in Corrosion Resistance, H. Shih, Ed., chapter 3, InTech, Shanghai, China, 2012.

[11] N. Baykal, J. Reggia, N. Yalabik, A. Erkmen, and M. Beksac, "The influence of nitrogen on the passivation of stainless steels," Corrosion Science, vol. 38, no. 7, pp. 1203-1220, 1996.

[12] H. Hänninen, J. Romu, R. Ilola, J. Tervo, and A. Laitinen, "Effects of processing and manufacturing of high nitrogen-containing stainless steels on their mechanical, corrosion and wear properties," Journal of Materials Processing Technology, vol. 117, no. 3, pp. 424-430, 2001.

[13] J. Tervo, J. Romu, E. Hamalainen, H. Hanninen, and J. Liimatainen, "Properties of P/M high nitrogen austenitic and duplex stainless steels," in Proceedings of the 5th International Conference on Advanced Particulate Materials and Processes, pp. 317329, West Palm Beach, Fla, USA, 1977.

[14] H. Katak and B. Raj, Corrosion of Austenitic Stainless SteelsMechanism, Mitigation and Monitoring, Narosa Publishing House, New Delhi, India, 2002.

[15] W. Clarke, W. Romero, and I. Danko, "Detection of sensitization in stainless steel using electrochemical techniques," in Proceedings of NACE Corrosion Conference (Corrosion '77), no. 180, Houston, Tex, USA, 1977.

[16] P. Novák, P. Štefec, and R. Franz, “Testing the susceptibility of stainless steels to intergranular corrosion by reactivation method," Corrosion, vol. 31, pp. 344-347, 1975.

[17] A. P. Majidi and M. A. Streicher, "Potentiodynamic reactivation method for detecting densitization in AlSl 304 and 304L stainless steels," Corrosion, vol. 40, no. 8, pp. 393-408, 1984.

[18] V. Kain, R. C. Prasad, and P. K. De, "Testing sensitization and predicting susceptibility to intergranular corrosion and intergranular stress corrosion cracking in austenitic stainless steels," Corrosion, vol. 58, no. 1, pp. 15-37, 2002.
[19] J. W. Simmons, “Overview: high-nitrogen alloying stainless steels," Material Science \& Engineering, vol. 207, pp. 159-169, 1996.

[20] R. F. A. Jargelius-Pettersson, "Application of the pitting resistance equivalent concept to some highly alloyed austenitic stainless steels," Corrosion, vol. 54, no. 2, pp. 162-168, 1998.

[21] A. Almubarak, M. Belkharchouche, and A. Hussain, "Stress corrosion cracking of sensitized austenitic stainless steels in Kuwait petroleum refineries," Anti-Corrosion Methods and Materials, vol. 57, no. 2, pp. 58-64, 2010.

[22] M. Pozuelo, J. E. Wittig, J. A. Jiménez, and G. Frommeyer, "Enhanced mechanical properties of a novel high-nitrogen Cr-Mn-Ni-Si austenitic stainless steel via TWIP/TRIP effects," Metallurgical and Materials Transactions A, vol. 40, no. 8, pp. 1826-1834, 2009.

[23] R. W. Ross, "New technology stainless steels and nickel alloys for marine applications in the year 2000 and beyond," in Proceedings of Oceans 2000 MTS/IEEE Conference and Exhibition, vol. 3, pp. 1597-1505, Piscataway, NJ, USA, 2000. 

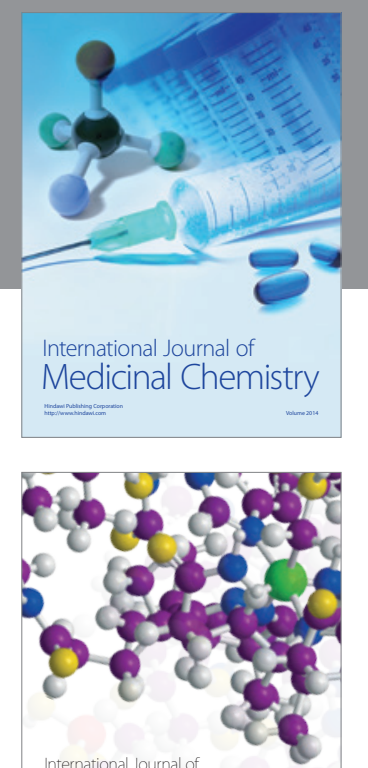

\section{Carbohydrate} Chemistry

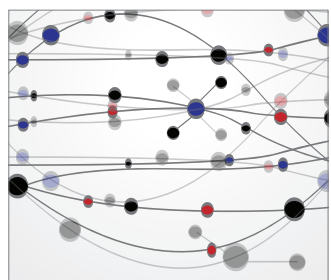

The Scientific World Journal
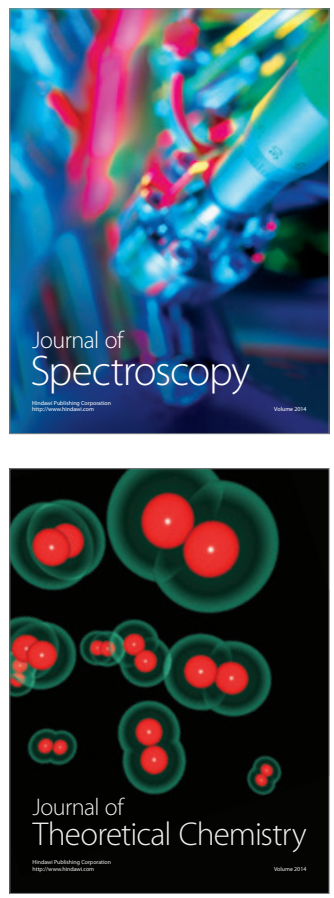
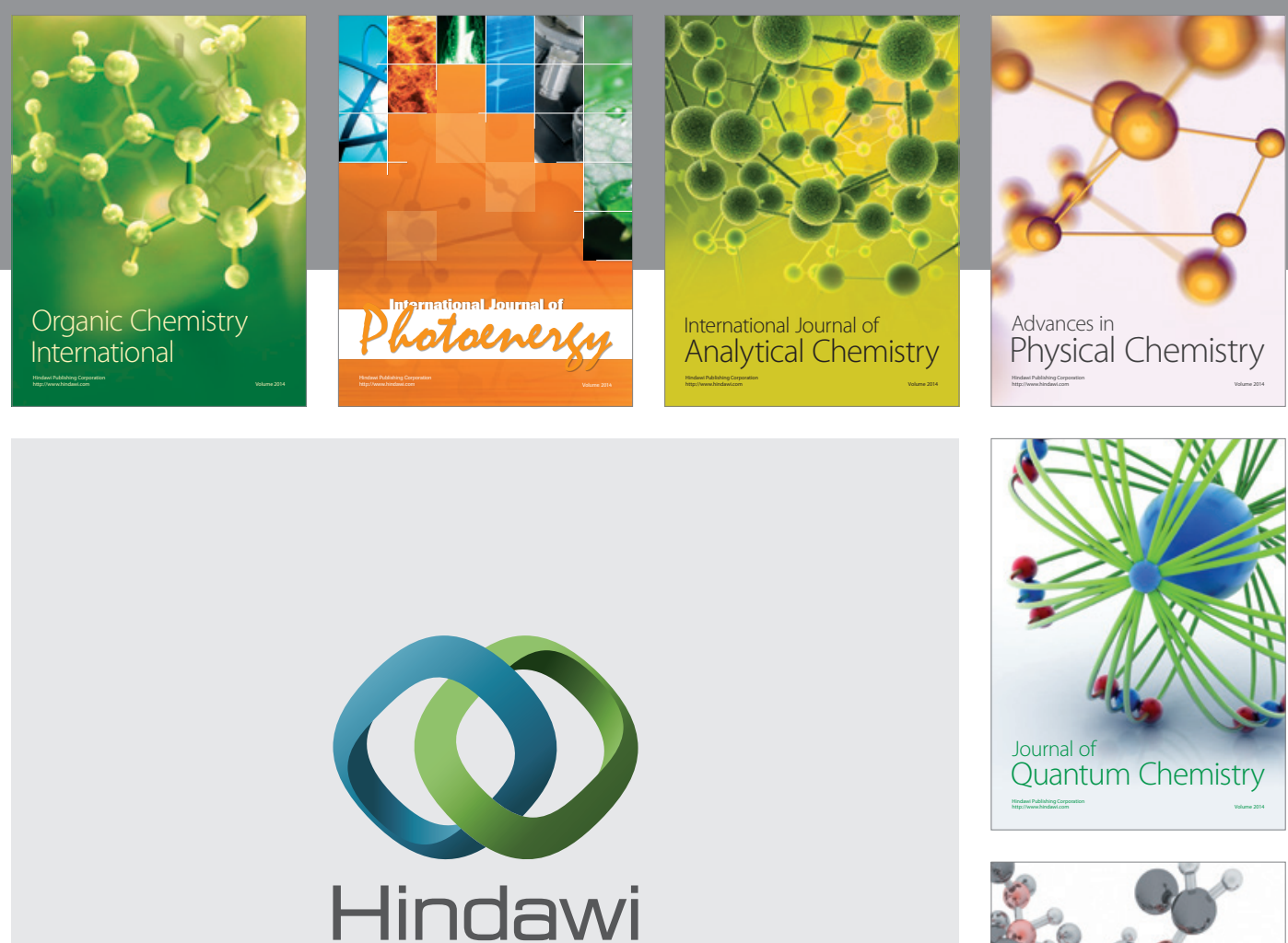

Submit your manuscripts at

http://www.hindawi.com

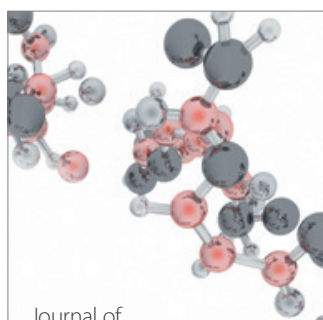

Analytical Methods

in Chemistry

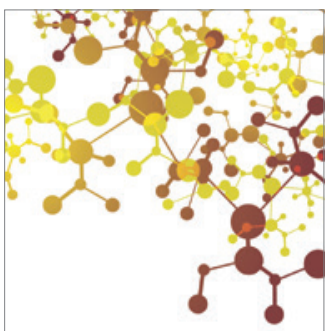

Journal of

Applied Chemistry

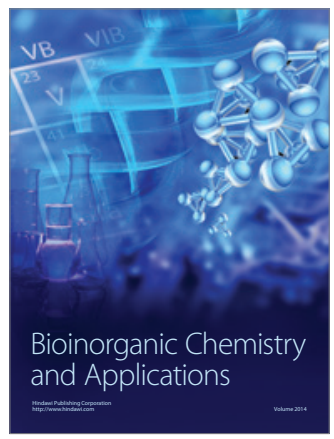

Inorganic Chemistry
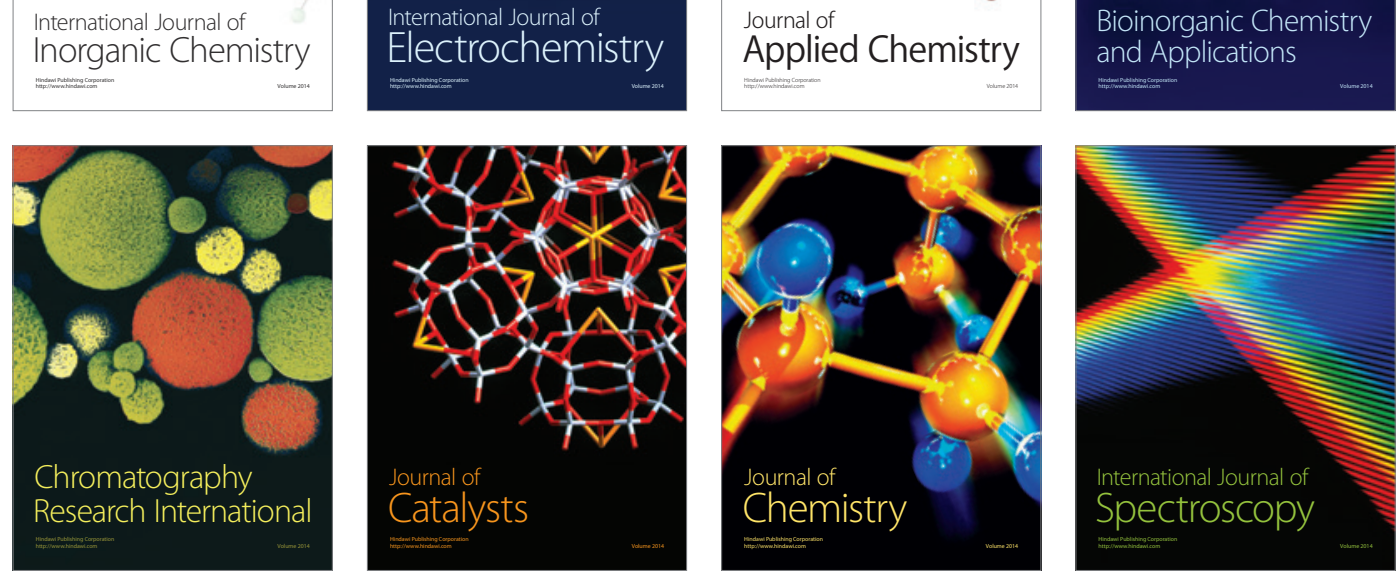